\title{
Exploring the Relationship Between Language Learning Strategies, Academic Achievement, Grade Level, and Gender
}

\author{
Senad Bećirovićn , Amna Brdarević-Čeljo', Edda Polz ${ }^{2}$ \\ ${ }^{1}$ International Burch University, Sarajevo, Bosnia and Herzegovina \\ ${ }^{2}$ University College of Teacher Education in Lower Austria, Baden, Austria \\ Correspondence concerning this article should be addressed to Senad Bećirović, International Burch \\ University, Francuske revolucije bb, 71210 Ilidža, Sarajevo, Bosnia and Herzegovina. \\ E-mail: senad.becirovic@ibu.edu.ba
}

\begin{abstract}
Learning efficacy can be substantially improved through the frequent use of learning strategies, whose practicality has been confirmed through extensive research. Thus, the purpose of the current study is to contribute to this wealth of research by determining whether learning strategies are significant predictors of students' achievement in learning English as a foreign language (EFL) as well as by exploring strategy awareness and variations in strategy use by gender, grade level, and overall grade point average (GPA) among 206 high school students. The results indicated that cognitive strategies are significant positive predictors, while memory and affective strategies are significant negative predictors of students' achievement in foreign language learning. Moreover, the findings revealed a significant impact of overall GPA and an insignificant impact of gender and grade level on the use of strategy subtypes, with the most frequently used strategies being metacognitive and the least frequently used being affective strategies. Furthermore, this research highlights the importance of incorporating strategiesbased instruction methods into foreign language curriculums in the Bosnian context and also aims to raise teachers' awareness of the importance of their application in the classroom milieu.
\end{abstract}

Keywords: language learning strategies, grade level, GPA, gender, achievement

\section{Introduction}

In the last few decades, language education has witnessed a progressive shift of focus from teaching to learning and the responsibility for learning has slowly transferred to the learners themselves, who have become the focal point of both processes and education research. The main concern of educational theorists has been learner autonomy (Little, 1991), which, if achieved, can enhance the effectiveness of the overall learning process. As claimed by Wong and Nunan (2011), two dimensions that can help students become effective and autonomous learners are learning strategies and learning-how-to-learn, which need to be incorporated into curricula, and language curricula in particular.

Learning strategies, particularly language learning strategies, appear to be among the major factors impacting second or foreign language (L2) performance and helping establish how and how well language learners acquire a second or a foreign language (Oxford, 2003). They have captured special research attention, with the findings predominantly pointing to their efficacy across different groups of learners and demonstrating the effectiveness of their practical implementation through adequate strategy instruction. Thus, the current study aims to reveal how strongly and adequately language learning strategies are represented in the Bosnian context through systematic exploration of their use and patterns of variation by gender, grade level, and grade point average. As a strategic approach to language learning can result in an increase in language proficiency, any research that might contribute to the adoption of such an approach is very useful. This is particularly so in the EFL context of Bosnia and Herzegovina where English proficiency is deemed indispensable due to the language's widespread and noticeable presence across different domains (Dubravac et al., 2018). 


\section{Literature Review}

Language learning strategies are particular actions employed by language learners to ease their development of foreign language skills (Green \& Oxford, 1995). They incorporate and foster awareness and conscious mastery over language learning (Schraw, 1998), thus increasing learner autonomy and making the learning process faster, simpler, more enjoyable, as well as more self-directed and effective (Little, 1991; Oxford, 2001). Definitions and classifications of language learning strategies have been very diverse (Cohen, 2007; Griffiths \& Oxford, 2014; O’Malley \& Chamot, 1990; O’Malley et al., 1985; Oxford, 1990; Oxford \& Cohen, 1992) and it has been claimed that they can be confusing and lack hierarchical arrangement (O'Malley et al., 1985; Oxford, 1990). Likewise, the concept of strategies itself has been referred to as "fuzzy" (Ellis, 1994, p. 529) and "elusive" (Wenden \& Rubin, 1987, p. 7). Still, one classification has surfaced as the most comprehensive one and that is Oxford's taxonomy of language learning strategies (SILL in Oxford, 1990). This taxonomy groups language learning strategies into direct and indirect ones, the former directly involving the target language through revising and practicing, and the latter indirectly easing the process of language learning through planning, collaborating and finding opportunities. Direct language learning strategies are further classified into memory (related to learning and retrieving new information via sounds, images, body movements, and other ways), compensation (related to compensating for their knowledge gaps through the use of synonyms, talking around the missing word, etc.) and cognitive strategies (related to thinking about the language, deep analysis, notetaking, and summarizing to produce knowledge structures). On the other hand, indirect language learning strategies are grouped into affective (related to the ability to identify feelings and discuss them, as well as to the use of positive self-encouragement), metacognitive (which include good management of the learning process through planning tasks and evaluating accomplishments, etc.), and social strategies (which involve an interaction with other students as a significant component of the learning process through asking for help or clarification) (Oxford, 1990; 2003). This strategy inventory is claimed to provide a solid theoretical base for understanding language learning strategies (Griffiths, 2004) despite the criticism it faced and it has been used as such in numerous studies, the current study being one of them.

The research approach to language learning strategies using Oxford's inventory as a theoretical construct has been multifaceted and focused on establishing whether the use of strategies is associated with L2 proficiency, which strategies are used most extensively, whether and how strategy awareness can be developed, and whether individual learner differences, inborn or acquired, have an impact on strategy use. A large number of studies explored which learning strategies are more frequently employed by L2 learners in different contexts (Cohen et al., 1998; Habók \& Magyar, 2018; Magogwe \& Oliver, 2007; Nyikos \& Oxford, 1993; Oxford \& Burry-Stock, 1995; Wharton, 2000; Wu, 2008). No common pattern can be established, but a very common strategy use order was compensation, metacognitive, and cognitive strategies ( $\mathrm{Wu}, 2008)$ as well as social, metacognitive, and cognitive strategies (Habók \& Magyar, 2018; Magogwe \& Oliver, 2007), with the order as well as specific strategy use being dependent upon students' age (Habók \& Magyar, 2018; Magogwe \& Oliver, 2007), gender (Ehrman \& Oxford, 1989; Goh \& Foong, 1997, Green \& Oxford, 1995; Oxford \& Nyikos, 1989), and very frequently upon the context in which the research was conducted, as claimed by Chamot (2004).

A close link has also been established between learning strategies and L2 proficiency (Agathopoulou, 2016; Griffiths \& Oxford, 2014), with more proficient students using language learning strategies more frequently than less proficient students (Dreyer \& Oxford, 1996; Habók \& Magyar, 2018; Magogwe \& Oliver, 2007; Oxford \& Ehrman, 1995; Wharton, 2000; Wu, 2008). Most strategy subtypes have been found significantly associated with L2 proficiency in different EFL and ESL contexts, namely cognitive (Oxford \& Ehrman, 1995; Wu, 2008), metacognitive (Dreyer \& Oxford, 1996), compensation (Oxford \& Ehrman, 1995), and affective and social strategies (Dreyer \& Oxford, 1996; Oxford \& Ehrman, 1995). On the other hand, no positive relation has been found between memory strategies and L2 proficiency (Wu, 2008) and in some studies these strategies even exhibit a negative impact on students' performance (Purpura, 1997). In Wu (2008), the difference in the use of language learning strategies by higher and lower proficiency students was significant overall and individually for all the strategy subtypes except for memory strategies, but the impact of cognitive strategies on L2 proficiency was most profound. Only in some studies was the difference in the use of memory strategies between lower and higher proficiency students found to be significant (Habók \& Magyar, 2018), with a significant difference between younger low and high proficiency students existing in the use of memory, cognitive, metacognitive, and social strategies, and between older students of opposing proficiency levels in the use of all strategy subtypes. 
Some research studies also explored the impact of strategy usage on overall academic achievement (Delić \& Bećirović, 2017; Habók \& Magyar, 2018; Shawer, 2016). Namely, Habók and Magyar (2018) measured how language learning strategies impact foreign language attitudes and through this, two other variables, namely foreign language marks and average general GPA, i.e. general school achievement, of the fifth and eighth grade students. The findings indicated that the impact of strategies on attitudes towards foreign language learning was rather high in the fifth grade, particularly within the domain of metacognitive strategies, and that attitudes towards the foreign language produced a significant effect on foreign language marks. Similar findings were confirmed in the eighth grade, as the effect of the eighth grade students' strategy usage on foreign language attitudes was also rather high, with metacognitive strategies having the highest effect, memory strategies the lowest effect, and the effect of social strategies being non-existent. Moreover, the impact of foreign language attitudes on students' foreign language marks was remarkably similar to the one measured in the fifth grade, while the impact of foreign language marks on general school achievement increased twice as much when compared to the impact measured in the fifth grade (Habók \& Magyar, 2018). Shawer (2016) also showed that language learning strategy subtypes jointly predicted academic achievement, but that only social and metacognitive strategies were found to be significant predictors.

Language learners are often not completely aware of the practicality of language learning strategies, and they cannot exploit their full potential unless they receive proper instruction and utilize them appropriately and more widely (Dervić \& Bećirović, 2019; Nyikos \& Oxford, 1993; Oxford, 1990). Hence, strategies-based instruction has also captured research attention (Gunning \& Oxford, 2014; Rubin et al., 2007) and some new instructional models have been proposed (Chamot \& O’Malley, 1996; Cohen, 1998).However, although teachers play a prominent role in the process of strategy instruction, the learning process starts with the learners themselves, and varies according to learners' individual differences, such as age, gender, education, and other factors that have been proven to affect strategy usage and the learning process (Oxford et al., 2018).

The largest variation in the use of strategies can be found with respect to gender and the research has commonly pointed to mixed gender-related findings (Takeuchi et al., 2007). Gender has thus often surfaced as a significant factor impacting strategy usage (Doró \& Habók, 2013; Ehrman \& Oxford, 1989; Goh \& Foong, 1997, Green \& Oxford, 1995; Kazamia, 2016; Oxford \& Nyikos, 1989), but has also frequently proven to be insignificant (Brdarević-Čeljo \& Asotić, 2017; Radwan, 2011; Wharton, 2000). Generally, females use strategies more frequently than males, either all of the strategy subtypes (Doró \& Habók, 2013; Goh \& Foong, 1997; Green \& Oxford, 1995) or only some of them (Ehrman \& Oxford, 1989; Oxford \& Nyikos, 1989; Yilmaz, 2010) and have frequently been reported to be better language learners (Ellis, 1994). However, in some studies, males reported using strategies slightly more frequently than females, either all strategy subtypes (Wharton, 2000) or only some (Brdarević-Čeljo \& Asotić, 2017; Radwan, 2011). Takeuchi et al. (2007) specifically pointed to the discrepancy in gender-related learning strategy research and stated that care needs to be taken when claiming that females are better language learners.

Grade level, correlative to age, has also been explored as a factor impacting strategy use, although to a lesser extent than gender. It has also been shown that the grade level is a significant factor impacting learning strategy use (Brdarević-Čeljo \& Asotić, 2017; Chen, 2009; 2014; Gavriilidou \& Petrogiannis, 2016; Magogwe \& Oliver, 2007; Oxford \& Nyikos, 1989), with only a few studies demonstrating that the impact is insignificant (e.g. Doró \& Habók, 2013). Hence, Chen (2009) indicated that a preference for strategy usage significantly changes over the years and there is a relationship between grade level and all strategy subtypes individually. In addition, Chen's (2014) and Magogwe and Oliver's (2007) comprehensive research conducted at all educational levels, namely at elementary, secondary and tertiary levels, revealed significant differences between strategy usage and grade level, with some differences in the use of specific strategy subtypes emerging. Similar results were obtained in the Greek EFL context. Gavriilidou and Petrogiannis (2016) pointed to significant differences in the use of language learning strategies between elementary and high school students, with younger elementary-level students achieving higher scores and thus were considered more frequent strategy users than older high school students. Mitits et al. (2016) also indicated that elementary school students use all language learning strategies except for compensation strategies significantly more frequently than high school students. However, when only high school students, aged 13 to 15, were included in the research (Kazamia, 2016), the results revealed that the difference in strategy usage was significant only in the domain of compensation strategies. 


\section{The Present Study and Hypotheses}

Research into factors impacting language learning strategies spans different socio-cultural contexts, but has never been carried out in the Bosnian context, particularly in the high school educational milieu. Even though strategy research is extensive, not all of the factors have been equally researched, for example grade level (Chen, 2009; 2014; Takeuchi et al., 2007), and those researched broadly, gender in particular, quite often yield rather conflicting results. Thus, a need for research into language learning strategies has often been highlighted (Chen, 2009), with a particular emphasis placed on factors determining strategy use. Thus, the present study aims to add to the previous research by determining whether the use of language learning strategies predicts students' achievement in learning English as a foreign language and whether the use varies according to students' gender, grade level, and general school achievement, i.e. students' overall GPA. By identifying factors that impact or are impacted by strategy usage, the study also aims to offer new insights and develop clear guidelines on how strategies ought to be taught in the EFL context of Bosnia and Herzegovina. Based on the adopted approach, the following hypotheses will be tested:

H1 There will be a statistically significant difference in the application of language learning strategies based on grade level.

H2 Students' overall GPA will have a significant impact on the application of language learning strategies.

H3 There will be a statistically significant difference in the application of language learning strategies based on gender.

H4 Language learning strategies, namely memory, compensation, cognitive, affective, metacognitive, and social, will be significant predictors of students' achievement in learning English as a foreign language.

\section{Materials and Methods}

\section{Participants}

Stratified random sampling was employed in the process of participant selection. This method of participant selection requires the recruitment of participants "based on their membership in a particular subgroup or stratum" (Vanderstoep \& Johnson, 2008, p. 32). The research sample comprised 206 students studying in high schools in Bosnia and Herzegovina, including 92 (44.7\%) female and 114 (55.3\%) male students, with an age range from 15 to $18(M=17.1, S D=1.01)$. Of the 206 participants, $38(18.4 \%)$ attend the first grade, $36(17.5 \%)$ the second grade, $107(51.9 \%)$ the third grade, and $25(12.1 \%)$ attend the fourth grade. In this sample, 75 students (36.4\%) achieved the highest overall GPA, ranging between 4.5 and 5.0. Half of the students, namely 103, have an overall GPA between 3.5 and 4.4, while 21 students (10.2\%) obtained a GPA between 2.5 and 3.4. Seven students (3.4\%) with a failing overall GPA were excluded from further calculations as the number of participants in question was below the threshold for the application of adequate statistical tests. With reference to students' GPA in English, 62 students (30.1\%) achieved the highest grade, that is 5, 54 students (26.2\%) received grade $4,42(20.4 \%)$ attained grade 3 , and 46 (22.3\%) grade 2 . Only two participants (1.0\%) received a failing grade and were thus excluded from further analysis, the reason for that being the same as the one cited for the overall GPA (Table 1).

\section{Table 1}

Descriptive analysis of the participants

\begin{tabular}{llcc}
\hline & & N & Percent \\
\hline Grade level & $1^{\text {st }}$ & 38 & 18.4 \\
& $2^{\text {nd }}$ & 36 & 17.5 \\
& $3^{\text {rd }}$ & 107 & 51.9 \\
& $4^{\text {th }}$ & 25 & 12.1 \\
\hline Gender & Female & 92 & 44.7 \\
& Male & 114 & 55.3 \\
\hline
\end{tabular}




\begin{tabular}{llcc}
\hline & & N & Percent \\
\hline GPA in English & 1 & 2 & 1.0 \\
& 2 & 46 & 22.3 \\
& 3 & 42 & 20.4 \\
& 4 & 54 & 26.2 \\
& 5 & 62 & 30.1 \\
\hline GPA in general & 1.0 & 7 & 3.4 \\
& $2.5-3.4$ & 21 & 10.2 \\
& $3.5-4.4$ & 103 & 50.0 \\
\hline Total & $4.5-5.0$ & 75 & 36.4 \\
\hline
\end{tabular}

\section{Assessments and Measures}

For data collection, the Strategy Inventory for Language Learning (SILL), originally devised and validated by Oxford (1990), was applied. Overall, the instrument comprises 50 items using a 5-point Likert scale, ranging from 1 ("Never or almost never true of me") to 5 ("Always or almost always true of me"). It is composed of six language learning strategy subscales, namely A, "memory", containing 9 items (e.g. "I use flashcards to remember new FL words") B, "cognitive", consisting of 14 items (e.g. "I try to find patterns in the FL"), C, "compensation", incorporating 6 items (e.g. "When I can't think of a word during a conversation in the FL, I use gestures"),D, “metacognitive”, containing 9 items (e.g. "I try to find out how to be a better learner of the FL"), E, "affective", including 6 items (e.g. "I talk to someone else about how I feel when I am learning the FL"), and F, "social", with 6 items (e.g. "I practice the FL with other students"). The reliability of data was determined by means of Cronbach's alpha, which shows acceptable and high levels of internal consistency: memory $\alpha=.69$, cognitive $\alpha=.78$, compensation $\alpha=.85$, metacognitive $\alpha=.74$, affective $\alpha=.68$, and social $\alpha=.78$, with the internal consistency of the combined dependent variable of language learning strategy being $\alpha=.92$.

Besides the Strategy Inventory for Language Learning (SILL), the questionnaire included demographic items, namely the students' grade level, overall GPA, GPA in English as a foreign language, gender, and age. There are two types of high schools in Bosnia and Herzegovina, namely grammar schools and vocational schools, and the English language is taught as a mandatory curricular EFL course in both. The number of hours of English language classes varies and is different in these two school types. In grammar schools, the curricular requirement of three hours of classes per week needs to be met, whereas in vocational schools the number is reduced to two. The current study's participants were proportionally selected from both types of schools. Thus, one group is neither overrepresented nor underrepresented (Vanderstoep \& Johnson, 2008). Concerning students' GPA, it should be noted that in the school system in Bosnia and Herzegovina, 5 is the highest grade, while 1 is the lowest (failing) grade. The data on students' overall GPA and grade in their English language course were received from class instructors and they refer to the summative final grades obtained at the end of the fall semester of the academic year 2019/20.

After obtaining informed consent from the schools' administration, school instructors, and students themselves, the instrument was administered to the students during regular classes on school premises. The participants were asked to read each survey statement carefully and respond to it sincerely. The average time needed for completing the survey was 15 minutes.

\section{Data Analysis}

Data analysis was performed by using the Statistical Package for the Social Sciences (SPSS), version 23. As the first step in the process, the data were examined for missing data as well as for outliers. Descriptive statistical analyses, including means, standard deviation, and frequencies, were conducted. Cronbach's alpha coefficient was calculated to determine the internal consistency. In order to identify correlations between language learning strategies, the Pearson product-moment correlation coefficient was computed. Before testing the hypothesis, the underlying assumptions for the application of multivariate statistical procedures in terms of normality, linearity, homoscedasticity, and homogeneity of variance-covariance matrices were examined and 
confirmed (Mertler \& Reinhart, 2016). The hypotheses were tested by performing a one-way MANOVA and a standard multiple regression analysis. In the MANOVA tests, students' grade levels, GPA, and gender were independent variables, while the six language learning strategies were dependent variables. A standard multiple regression analysis was performed to examine how the six language learning strategies predicted the students' EFL achievement.

\section{Results}

According to the conducted descriptive analysis, the students achieved the highest score in the use of metacognitive strategies $(M=3.54, S D=.79)$, followed by cognitive $(M=3.41, S D=.65)$, and compensation strategies $(M=3.28, S D=.71)$, then social $(M=3.09, S D=.93)$ and memory strategies $(M=3.07, S D=.64)$. The least frequently used strategies were affective strategies $(M=2.67, S D=.79)$.

A Pearson product-moment correlation coefficient was computed to determine the correlations between the dependent variables. The strongest positive and significant correlations were found between cognitive and metacognitive learning strategies $(r=.73, p<.001)$, then social and cognitive $(r=.63, p<.001)$, social and metacognitive $(r=.58, p<.001)$, as well as between cognitive and compensation learning strategies $(r=.53, p<$ $.001)$. The associations between memory and cognitive $(r=.52, p<.001)$, and memory and metacognitive learning strategies $(r=.52, p<.001)$ were equally strong, positive, and significant. There was a medium, positive, and significant correlation between affective and social $(r=.46, p<.001)$, compensation and metacognitive $(r=.42, p<.001)$, compensation and social $(r=.42, p<.001)$, memory and social $(r=.42, p<.001)$, memory and affective $(r=.39, p<.001)$, metacognitive and affective $(r=.39, p<.001)$, memory and compensation $(r=.37, p<$ $.001)$, and between affective and compensation strategies $(r=.31, p<.001)$. Furthermore, the association between affective and cognitive learning strategies $(r=.25, p<.001)$ was small but positive and significant. Table 2 displays the descriptive statistics and correlations between the dependent variables.

Table 2

Means, standard deviations, reliabilities, and correlations for language learning strategies

\begin{tabular}{|c|c|c|c|c|c|c|c|c|c|c|c|}
\hline Strategy & $\mathbf{N}$ & $\mathbf{M}$ & SD & $\alpha$ & 1 & 2 & 3 & 4 & 5 & 6 & 7 \\
\hline Memory & 192 & 3.07 & .64 & .69 & 1 & & & & & & \\
\hline Cognitive & 192 & 3.41 & .65 & .78 & $.52^{* * *}$ & 1 & & & & & \\
\hline Compensation & 192 & 3.28 & .71 & .85 & $.37^{* * *}$ & $.53^{* * *}$ & 1 & & & & \\
\hline Metacognitive & 192 & 3.54 & .79 & .74 & $.52^{* * *}$ & $.73^{* * *}$ & $.42^{* * *}$ & 1 & & & \\
\hline Affective & 192 & 2.67 & .79 & .68 & $.39 * *$ & $.28^{* * *}$ & $.31^{* * *}$ & $.39 * *$ & 1 & & \\
\hline Social & 192 & 3.09 & .93 & .78 & $.42^{* * *}$ & $.63^{* * *}$ & $.42^{* * *}$ & $.58^{* * *}$ & $.46^{* * *}$ & 1 & \\
\hline All Strategies & 192 & 3.23 & .56 & .92 & $.72^{* * *}$ & $.87^{* * *}$ & $.65^{* *}$ & $.85^{* * *}$ & $.58^{* * *}$ & $78^{* * *}$ & 1 \\
\hline
\end{tabular}

Note. ${ }^{* *}$ Correlation is significant at the 0.01 level (2-tailed)

A one-way MANOVA was conducted to determine the differences in the application of language learning strategies based on grade level. The independent variable grade level comprised four groups $\left(1^{\text {st }}, 2^{\text {nd }}, 3^{\text {rd }}\right.$, and $4^{\text {th }}$ grade level) while the combined dependent variables of language learning strategies included six strategy subtypes, namely memory, cognitive, compensation, metacognitive, affective, and social. The outcomes of the one-way MANOVA revealed that grade level had no significant effect on the combined dependent variables of language learning strategies, Wilks' Lambda $\lambda=0.933, F(18,518.087)=.719, p=.792$, with a small effect size $\eta^{2}=.023$. Even though there was no significant influence of grade level on the combined dependent variables of language learning strategies, it was worth checking whether there was a significant influence of grade level on any of the individual dependent variables. Univariate ANOVA tests were conducted as follow-up tests. The analysis of variance on each dependent variable identified that grade level had no significant influence on any of language learning strategies, memory $F(18,518.087)=.902, p=.441, \eta^{2}=.014$, cognitive $F(18,518.087)=.638$, $p=.592, \eta^{2}=.010$, compensation $F(18,518.087)=1.317, p=.270, \eta^{2}=.021$, metacognitive $F(18,518.087)=.242$, $p=.867, \eta^{2}=.004$, affective $F(18,518.087)=1.187, p=.316, \eta^{2}=.019$, and social $F(18,518.087)=.576, p=.631$, $\eta^{2}=.009$. 
Table 3

Multivariate ANOVA between grade level groups on language learning strategies

\begin{tabular}{|c|c|c|c|c|c|c|c|c|c|c|}
\hline \multirow{2}{*}{ Strategy } & \multicolumn{2}{|c|}{$1^{\text {st }}$ grade } & \multicolumn{2}{|c|}{$2^{\text {nd }}$ grade } & \multicolumn{2}{|c|}{$3^{\text {rd }}$ grade } & \multicolumn{2}{|c|}{$4^{\text {th }}$ grade } & \multirow[b]{2}{*}{$\mathbf{p}$} & \multirow[b]{2}{*}{$\eta^{2}$} \\
\hline & $M$ & $S D$ & $M$ & $S D$ & $M$ & $S D$ & $M$ & $S D$ & & \\
\hline Memory & 3.00 & .68 & 2.94 & .61 & 3.13 & .63 & 3.12 & .64 & .441 & .014 \\
\hline Cognitive & 3.42 & .64 & 3.34 & .73 & 3.46 & .64 & 3.29 & .55 & .592 & .010 \\
\hline Compen. & 3.30 & .71 & 3.07 & .76 & 3.33 & .67 & 3.35 & .73 & .270 & .021 \\
\hline Metacog. & 3.47 & .88 & 3.47 & .87 & 3.57 & .77 & 3.59 & .68 & .867 & .004 \\
\hline Affective & 2.54 & .93 & 2.54 & .81 & 2.70 & .76 & 2.87 & .71 & .316 & .019 \\
\hline Social & 3.13 & .79 & 2.92 & 1.02 & 3.15 & .95 & 3.02 & .92 & .631 & .009 \\
\hline
\end{tabular}

Table 3 shows that metacognitive language learning strategies were the most commonly used strategies by students at all grade levels, $1^{\text {st }}$ grade $(M=3.47, S D=.93), 2^{\text {nd }}$ grade $(M=3.47, S D=.87)$, $3^{\text {rd }}$ grade $(M=3.57, S D=.77)$, and $4^{\text {th }}$ grade $(M=3.59, S D=.68)$. The second most frequently used strategies within the first three years were cognitive learning strategies, i.e. in the $1^{\text {st }}(M=3.43, S D=.54), 2^{\text {nd }}(M=3.34, S D=.73)$, and $3^{\text {rd }}$ grade $(M=3.46$, $S D=.64)$. In the fourth grade, the most frequently used strategies were compensation strategies $(M=3.35$, $S D=.73$ ). Likewise, compensation strategies were the third most frequently employed strategies in the $1^{\text {st }}$ $(M=3.30, S D=.71), 2^{\text {nd }}(M=3.07, S D=.76)$, and $3^{\text {rd }}$ grade $(M=3.33, S D=.67)$, while cognitive strategies were the third most frequently used strategies in the $4^{\text {th }}$ grade $(M=3.29, S D=.55)$. The fourth most commonly used strategies in the $1^{\text {st }}(M=3.23, \mathrm{SD}=.70)$ and $3^{\text {rd }}$ grade $(M=3.15, S D=.95)$ were social strategies, whereas the fourth most commonly used strategies in the $2^{\text {nd }}(M=2.94, S D=.61)$ and $4^{\text {th }}$ grade $(M=3.12, S D=.64)$ were memory strategies. Following these were memory strategies in the $1^{\text {st }}(M=3.00, S D=.68)$ and $3^{\text {rd }}$ grade $(M=3.13, S D=.63)$ and social strategies in the $2^{\text {nd }}(M=2.92, S D=1.02)$ and $4^{\text {th }}$ grade $(M=3.02, S D=.92)$. Affective strategies were the least commonly applied language learning strategies in all grades, namely in the $1^{\text {st }}(M=2.54, S D=.93), 2^{\text {nd }}$ $(M=2.54, S D=.81), 3^{\text {rd }}(M=2.70, S D=.76)$ and $4^{\text {th }}$ grade $(M=2.97, S D=.71)$.

A one-way MANOVA was also conducted to determine the differences in the use of language learning strategies based on overall GPA. The independent variable 'overall GPA' included three groups (low: 2.5-3.4, moderate: 3.5-4.4, and high 4.5-5.0), while the combined dependent variables of language learning strategies comprised the six aforesaid subscales.

The results of the one-way MANOVA indicated a significant influence of the overall GPA, Wilks' Lambda $\lambda=0.836, F(12,370)=2.873, p=.001$, with a medium effect size $\eta^{2}=.086$, on the combined dependent variable of language learning strategies. In order to provide further understanding of the usage of language learning strategies across different GPA groups, univariate ANOVA tests were conducted as follow-up tests. The analysis of variance on each dependent variable revealed that overall GPA had a significant influence on memory $F(12$, $370)=8.608, p<.001, \eta^{2}=.083$, cognitive $F(12,370)=7.797, p=.001, \eta^{2}=.076$, compensation $F(12,370)=3.273$, $p=.040, \eta^{2}=.033$, metacognitive $F(12,370)=5.034, p=.007, \eta^{2}=.051$, and affective strategies $F(12,370)=3.453$, $p=.034, \eta^{2}=.035$, but did not have a significant influence on social strategies $F(12,370)=2.850, p=.060, \eta^{2}=.029$.

\section{Table 4}

Multivariate ANOVA between GPA groups on language learning strategies

\begin{tabular}{|c|c|c|c|c|c|c|c|c|c|c|}
\hline \multirow{2}{*}{ Strategy } & \multicolumn{2}{|c|}{ 2.5-3.4 (low) } & \multicolumn{2}{|c|}{ 3.5-4.4 (medium) } & \multicolumn{2}{|c|}{ 4.5-5.0 (high) } & \multicolumn{2}{|c|}{ Total } & \multirow[b]{2}{*}{$p$} & \multirow[b]{2}{*}{$\eta^{2}$} \\
\hline & $M$ & $S D$ & $M$ & $S D$ & $M$ & $S D$ & $M$ & $S D$ & & \\
\hline Memory & 3.55 & .53 & 2.94 & .65 & 3.13 & .60 & 3.07 & .64 & $<.001$ & .083 \\
\hline Cognitive & 3.54 & .75 & 3.24 & .64 & 3.61 & .57 & 3.41 & .65 & .001 & .076 \\
\hline Compensation & 3.38 & .82 & 3.16 & .69 & 3.42 & .67 & 3.28 & .71 & .040 & .033 \\
\hline Metacognitive & 3.66 & .68 & 3.37 & .83 & 3.74 & .72 & 3.54 & .79 & .007 & .051 \\
\hline Affective & 2.93 & .85 & 2.53 & .84 & 2.78 & .68 & 2.67 & .79 & .034 & .035 \\
\hline Social & 3.43 & .76 & 2.95 & .91 & 3.19 & .97 & 3.09 & .93 & .060 & .029 \\
\hline
\end{tabular}


As presented in Table 4, metacognitive language learning strategies were the most frequently employed by all participants $(M=3.54, S D=.79)$ regardless of their overall GPA. Likewise, the students with the highest overall GPA (4.5-5.0) applied metacognitive strategies the most frequently $(M=3.74, S D=.72)$, followed by cognitive $(M=3.61, S D=.57)$, and compensation strategies $(M=3.42, S D=.67)$. Relatively less commonly used strategies were social $(M=3.19, S D=.97)$, memory $(M=3.13, S D=.60)$, and affective strategies $(M=2.78, S D=.68)$. The use of strategies by the students with the medium overall GPA level (ranging between 3.5 and 4.4) was equally ranked, with the use of metacognitive strategies being most frequent $(M=3.37, S D=.83)$, followed by cognitive $(M=3.24, S D=.64)$, compensation $(M=3.16, S D=.69)$, social $(M=2.95 S D=.91)$, memory $(M=2.94, S D=.65)$ and affective strategies $(M=2.53, S D=.84)$. The students with a low overall GPA (2.5-3.4) revealed somewhat different preferences in their strategy usage. While their most commonly applied language learning strategies were also metacognitive $(M=3.66, S D=.68)$, they were followed by memory strategies $(M=3.55, S D=.53)$, which were, rather interestingly, the second least used strategies by those students with a higher overall GPA. The third most frequently used strategy among the students with a low overall GPA was cognitive $(M=3.54, S D=.75)$, followed by social $(M=3.43, S D=.76)$, and compensation strategies $(M=3.38, S D=.82)$, the third most frequently used strategy by students with a higher overall GPA. Similar to the wo better performing groups, affective strategies $(M=2.93, S D=.85)$ were the least frequently used strategies among the students with a low overall GPA in the process of language learning.

A one-way MANOVA was also conducted to identify whether there were any differences in the application of language learning strategies based on gender. The results indicated that there was no significant difference in the use of language learning strategies between male and female students, Wilks' Lambda $\lambda=0.944, F(6$, $185)=1.839, p=.094$, with a medium effect size $\eta^{2}=.056$. Univariate ANOVA tests were conducted as follow-up tests for further understanding of the use of language learning strategies by female and male students. The analysis of variance on each of the six language learning strategy subscales shows that gender had a significant influence only on memory $F(6,185)=5.880, p=.016, \eta^{2}=.030$ and affective strategies $F(6,185)=7.389, p=.007$, $\eta^{2}=.037$. However, there was no significant effect of gender on cognitive $F(6,185)=2.239, p=.136, \eta^{2}=.012$, compensation $F(6,185)=.092, p=.763, \eta^{2}=.000$, metacognitive $F(6,185)=3.353, p=.069, \eta^{2}=.017$, and social strategies $F(6,185)=2.142, p=.145, \eta^{2}=.011$.

Table 5

Multivariate ANOVA between gender groups on language learning strategies

\begin{tabular}{|c|c|c|c|c|c|c|c|c|}
\hline \multirow{2}{*}{ Strategy } & \multicolumn{2}{|c|}{ Female } & \multicolumn{2}{|c|}{ Male } & \multicolumn{2}{|c|}{ Total } & \multirow[b]{2}{*}{$p$} & \multirow[b]{2}{*}{$\eta^{2}$} \\
\hline & $M$ & $S D$ & $M$ & $S D$ & $M$ & $S D$ & & \\
\hline Memory & 3.19 & .62 & 2.97 & .65 & 3.07 & .64 & .016 & .030 \\
\hline Cognitive & 3.49 & .65 & 3.35 & .64 & 3.41 & .65 & .136 & .012 \\
\hline Compensation & 3.30 & .75 & 3.26 & .75 & 3.28 & .71 & .763 & .000 \\
\hline Metacognitive & 3.65 & .80 & 3.44 & .78 & 3.54 & .79 & .069 & .017 \\
\hline Affective & 2.83 & .73 & 2.53 & .82 & 2.67 & .79 & .007 & .037 \\
\hline Social & 3.20 & .98 & 3.00 & .88 & 3.09 & .93 & .145 & .011 \\
\hline
\end{tabular}

As shown in Table 5, both female $(M=3.65, S D=.80)$ and male $(M=3.44, S D=.78)$ students applied metacognitive language learning strategies most frequently, followed by cognitive strategies (female $(M=3.49, S D=.65)$ and male $(M=3.35, S D=.64)$ ), and compensation strategies (female $(M=3.30, S D=.75)$ and male $(M=3.26, S D=.75)$ ). Social strategies were the fourth most frequently used strategies by female $(M=3.20, S D=.98)$ and male students $(M=3.00, S D=.88)$, followed by memory strategies (female $(M=3.19, S D=.62)$ and male $(M=2.97$, $S D=.65)$ ), while affective strategies were the least commonly used strategies by both female $(M=2.83, S D=.73)$ and male students $(M=2.53, S D=.82)$.

Students employ different learning strategies to acquire the content of various school subjects and these strategies might have a direct impact on their academic achievement. As for foreign language learning strategies, the model developed by Oxford (1990) was tested. Thus, a standard multiple regression analysis was carried out utilizing students' academic achievement learning English as a foreign language as a criterion variable and memory, cognitive, compensation, metacognitive, affective, and social language learning strategies 
as predictor variables to determine if students' academic achievement in learning English as a foreign language could be predicted by language learning strategies. The results of the regression were found to be statistically significant $\left[R^{2}=.218, R_{\text {adj }}^{2}=.192, F(6,185)=8.579, p<.001\right]$, indicating that language learning strategies (memory, cognitive, compensation, metacognitive, affective, and social) are good predictors of students' academic achievement in learning English as a foreign language. This model accounts for $22 \%$ of variance as indexed by the adjusted $\mathrm{R}^{2}$ statistic. A summary of regression coefficients is presented in Table 6 and shows that three strategy subtypes, namely memory $(B=-.546, p<.001)$, cognitive $(B=.505, p=.010)$, and affective strategies $(B=-.433, p<.001)$ contributed significantly to the model, while compensation $(B=.146, p=.247)$, metacognitive $(B=.152, p=.296)$, and social strategies $(B=.103, p=.356)$ did not.

\section{Table 6}

Coefficients for language learning strategies

\begin{tabular}{lcccccc}
\hline \multicolumn{1}{c}{ Strategy } & $\boldsymbol{B}$ & $\beta$ & $\boldsymbol{t}$ & $\boldsymbol{p}$ & Bivariate $\boldsymbol{r}$ & Partial $\boldsymbol{r}$ \\
\hline Memory & -.546 & -.311 & -3.825 & $<.001$ & -.156 & -.271 \\
Cognitive & .505 & .289 & 2.599 & .010 & .223 & .188 \\
Compensation & .146 & .091 & 1.160 & .247 & .114 & .085 \\
Metacognitive & .152 & .107 & 1.048 & .296 & .124 & .077 \\
Affective & -.433 & -.305 & -3.906 & $<.001$ & -.238 & -.276 \\
Social & .103 & .085 & .926 & .356 & .097 & .068 \\
\hline
\end{tabular}

The results suggest that memory and affective language learning strategies had a significant negative influence on students' EFL achievement, while cognitive language learning strategies had a significant positive effect on their EFL academic achievement. The effect of compensation, metacognitive, and social strategies was also positive but insignificant. Such findings indicate that as the students' use of memory and affective strategies increases, their EFL achievement tends to decrease, whereas their greater use of cognitive strategies causes an increase in their EFL achievement.

\section{Discussion and Conclusion}

The current study aimed at investigating the grade level, GPA, and gender-based differences in the use of language learning strategies, namely memory, cognitive, compensation, metacognitive, affective, and social, by high school students in Bosnia and Herzegovina. Furthermore, it sought to determine the influence of specific language learning strategy subtypes on students' L2 proficiency. Overall, the current study participants reported a high use of metacognitive strategies and a moderate use of cognitive, compensation, social, memory, and affective strategies, according to the assessment of strategy usage provided in Oxford and Burry-Stock (1995). The findings pointed to the most frequent use of metacognitive strategies, which lends support to some previous findings measuring the use of language learning strategies by means of SILL (Brdarević-Čeljo \& Asotić, 2017; Doró \& Habók, 2013; Green \& Oxford, 1995; Habók \& Magyar, 2018; Radwan, 2011). Green and Oxford (1995) and Goh and Foong (1997) reported the most frequent use of metacognitive strategies by students at all proficiency levels, which is not the case with Magogwe and Oliver's study (2007) indicating that high school and university-level students used metacognitive strategies most frequently, whereas elementary school students reported using social strategies most frequently followed by metacognitive. The least frequently used strategies were memory and affective learning strategies, which corroborates the findings of Yilmaz (2010), in which the overall pattern and order of strategy usage resembled the one presented in the current study. Due to the fact that the current study's participants are high school students who have already become reasonably proficient in their L2, these findings are not surprising and they point to the fact that these participants successfully plan L2 tasks, organize materials, detect their mistakes and manage the learning process overall, which indicates a high level of metacognition,but they do not use memory and affective strategies, i.e. memorization and self-encouragement as much.

The first hypothesis stating that there will be a significant difference in the participants' use of language learning strategies based on grade level was rejected, as the impact of grade level on the use of all language 
learning strategies was measured insignificant in the context of the current study. The most frequently used learning strategy subtype by students at all four grade levels was metacognitive, while the least frequently applied subtype was affective, with some slight differences existing in the ranking of the remaining strategy subtypes at different grade levels. These results appear to be well substantiated by the findings in Doró and Habók (2013) and Kazamia (2016), which also revealed insignificant differences in the high school students' use of language learning strategies. Devlin (1996) investigated the influence of maturity on the use of learning strategies and suggested that more mature students tend to apply more affective learning strategies than less mature students, which was not corroborated by the current study's findings.

Variations in the application of all or some strategy subtypes at different grade levels was observed and measured as significant in other studies (Bećirović et al., 2017; Brdarević-Čeljo \& Asotić, 2017; Chen, 2009; 2014; Gavriilidou \& Petrogiannis, 2016; Habók \& Magyar, 2018; Magogwe \& Oliver, 2007; Mitits et al., 2016), which is not aligned with the current study's findings, which even suggested that high school seniors reported the same or lower strategy use. This discordance with the stated results was slightly unanticipated as four years in the period of adolescence is a rather lengthy timeframe for students' cognitive and emotional development and increased self-awareness, and is expected to produce an increase in strategy awareness. However, such results might point to the fact that strategies-based instruction has not been properly implemented in language learning or teaching in high schools in Bosnia and Herzegovina and that language teachers should devote more attention to the development of strategy awareness in Bosnian high schools. This could be achieved through proper strategy instruction, which would entail language teachers introducing some new useful strategies and preparing some exercises developing them and leading to their more frequent use by language learners.

The second hypothesis proposing that there will be a significant difference in the students' usage of language learning strategies based on their overall GPA was supported. The results showed that the students with a higher overall GPA use metacognitive and cognitive language learning strategies significantly more frequently than those with a lower overall GPA. On the other hand, memory strategies were the second most frequently used strategies by students with the lower overall GPAs while they were the second least frequently used strategies by learners with middle to high overall GPAs. Such results confirm Habók and Magyar's (2018) findings, which showed that overall school achievement has a significant impact on the application of language learning strategies and that high performing students are frequent users of metacognitive strategies. They are also in concordance with Shawer's (2016) findings indicating that the use of strategies overall and metacognitive and social strategies individually predict students' general school achievement.

Thus, the students with a higher overall GPA seem to have expanded their strategy usage far beyond language learning and they used them across disciplines, which contributed to their overall achievement. This is particularly the case with metacognitive and cognitive strategies, which have proven highly efficient due to their ability to manage the learning process and orchestrate the material through the use of higher-order thinking skills (Oxford, 1990; 2003). A possible explanation for the current findings might be that less successful high school learners use lower-level thinking skills, such as memorisation, more frequently than the more successful ones (Marzano \& Kendall, 2007). Thus, the current study's participants with higher overall achievement have been shown to be more successful strategy users who exploit strategies, particularly metacognitive and cognitive strategies, in the process of learning, both language learning and beyond, than the students with a lower overall achievement.

The third hypothesis suggesting that there would be a significant difference in the application of language learning strategies based on gender was rejected, as no significant differences between male and female learners in the use of language learning strategies in the context of the present study were identified. Regardless of gender, the students shared the same preferences for learning strategies, with females using each strategy subtype more frequently than their male colleagues but to an insignificant extent. The current study's findings are in concordance with some previous findings where gender-related insignificancy in strategy usage was observed (Brdarević-Čeljo \& Asotić, 2017; Radwan, 2011; Wharton, 2000). Still, in the aforementioned studies, males were reported to be more frequent strategy users than females, which was not substantiated by the current findings indicating a higher strategy usage by females than males, similar to Doró and Habók (2013), Goh and Foong (1997) and Green and Oxford (1995). The current study's results are not aligned with the research findings of some other studies conducted in the same socio-cultural context (Bećirović, et al., 2017, Bećirović et al., 2018, Mašić et al., 2020), which pointed to significant differences in strategy use.However, the 
results are in line with Bećirović (2017), whose study showed no significant influence of gender on students' achievement in EFL learning, and Rizvić and Bećirović (2017), who identified no significant differences between female and male learners regarding their willingness to communicate in English as a foreign language.

The present study also aimed to explore whether language learning strategies are significant predictors of students' achievement in learning English as a foreign language and the results indicated that cognitive strategies have a significant positive effect while compensation, metacognitive, and social strategies have an insignificant positive effect on L2 achievement. On the other hand, memory and affective language learning strategies have a significant negative impact on L2 achievement. Such results confirm some previous findings, which also indicated that cognitive strategies have the most profound effect on L2 proficiency (Wu, 2008) and that memory strategies are not positively related to L2 proficiency $(\mathrm{Wu}, 2008)$ and even have a negative impact on students' performance (Purpura, 1997), as well as that affective strategies have negative effects on foreign language attitudes and L2 proficiency (Habók \& Magyar, 2018). During the process of achieving L2 proficiency, learners are more in need of cognitive, metacognitive, and social strategies than affective and memory strategies (Oxford, 2003), and this was confirmed by the current study's findings, which even indicated that these strategies negatively impact the participants' L2 learning. One of the possible explanations for the negative impact of memory and affective strategies in the present study could be that the participants' time spent receiving formal English language instruction is seven to eleven years and they are now at higher stages of language learning and have made considerable progress towards L2 proficiency and thus do not need these strategies as much as they needed them in their initial stages of language learning. The greater use of other strategies by these high school participants, cognitive strategies in particular, causes an increase in self-efficacy and L2 proficiency (Oxford, 2003), which obviates their need to use affective and memory strategies and to rely on different forms of positive self-talk, self-reward, or memorization of vocabulary or language structures at this stage of language learning.

This study has some important pedagogical implications, as it might help develop strategy awareness and highlight the need to incorporate strategies-based instruction in the foreign language curriculum. Hence, a language teacher can discuss strategy usage within the class and ask students to prepare a list of the strategies they employ. While analysing the lists, the teacher needs to take students' individual differences into consideration, i.e. their gender, grade level, GPA, and L2 proficiency and based on that adopt a different approach to strategy teaching for each group with similar characteristics. Then, the teacher might introduce some new useful strategies and consciously focus on providing specific exercises that develop these strategies and lead to their more frequent use. Eventually, teachers may also encourage students to start thinking about adopting a personal strategic approach towards language learning and the learning process in general, which will help them achieve learner autonomy.

Some limitations and suggestions for further research also need to be noted and taken into consideration for similar future research endeavours. Namely, students' English language proficiency was measured by the summative GPA in their English language courses. Although these grades are awarded by certified EFL teachers, a proficiency test might give a clearer picture of students' real EFL performance. Likewise, the research sample included participants from grammar and vocational schools. Further research may incorporate the differences in the usage of language learning strategies between students studying at different types of schools.

\section{Conflicts of interest}

The authors declare that they have no conflicts of interest.

\section{References}

Agathopoulou, E. (2016). Factors affecting language learning strategy use by learners of English at Greek secondary schools: Proficiency and motivation. In Z. Gavriilidou, \& K. Petrogiannis (Eds.), Language learning strategies in the Greek setting: Research outcomes of a large-scale project (pp. 58-75). Saita Publications.

Bećirović, S. (2017). The relationship between gender, motivation and achievement in learning English as a foreign language. European Journal of Contemporary Education, 6(2), 210-220. https://doi.org/10.13187/ 
ejced.2017.2.210

Bećirović, S., Brdarević-Čeljo, A., \& Dubravac, V. (2018). The effect of nationality, gender, and GPA on the use of reading strategies among EFL university students. Sage Open, 8(4), 1-12. https://doi. org/10.1177/2158244018809286

Bećirović, S., Brdarević-Čeljo, A., \& Sinanović, J. (2017). The use of metacognitive reading strategies among students at International Burch University: A case study. European Journal of Contemporary Education, 6(4), 645-655. https://doi.org/10.13187/ejced.2017.4.645

Brdarević-Čeljo, A., \& Asotić, M. (2017). The Influence of social context, grade level and gender on the use of language learning strategies in primary schools. Imperial Journal of Interdisciplinary Research, 3(12), 7-14.

Chamot, A. U. (2004). Issues in language learning strategy research and teaching. Electronic Journal of Foreign Language Teaching, 1(1), 14-26.

Chamot, A. U., \& O’Malley, J. M. (1996). The cognitive academic language learning approach: A model for linguisticallydiverseclassrooms.TheElementarySchoolJournal,96(3),259-273.https://doi.org/10.1086/461827

Chen, M. L. (2009). Influence of grade level on perceptual learning style preferences and language learning strategies of Taiwanese English as a foreign language learners. Learning and Individual Differences, 19(2), 304-308. https://doi.org/10.1016/j.lindif.2009.02.004

Chen, M. L. (2014). Age differences in the use of language learning strategies. English Language Teaching, 7(2), 144-151. https://doi.org/10.1086/461827.5539/elt.v7n2p144

Cohen, A. D. (1998). Strategies in learning and using a second language ( $2^{\text {nd }}$ ed.). Longman Applied Linguistics.

Cohen, A. D. (2007). Coming to terms with language learner strategies: Surveying the experts. In A. D. Cohen, \& E. Macaro (Eds.), Language learner strategies: 30 years of research and practice (pp. 29-45). Oxford University Press.

Cohen, A. D., Weaver, S. J., \& Li, T. Y. (1998). The impact of strategies-based instruction on speaking a foreign language. In A. D. Cohen (Ed.), Strategies in learning and using a second language (pp. 107-156). Longman.

Delić, H., \& Bećirović, S. (2017). The influence of grade point average and socioeconomic status on learning strategies. Journal of Education and Humanities, 1(2), 53-64. https://doi.org/10.14706/jeh2018123

Dervić, M., \& Bećirović, S. (2019). Native and non-native EFL teachers dichotomy: Terminological, competitiveness and employment discrimination. Journal of Language and Education, 5(3), 114-127. https:// doi.org/10.17323/jle.2019.9746

Devlin, M. (1996). Older and wiser?: A comparison of the learning and study strategies of mature age and younger teacher education students. Higher Education Research \& Development, 15(1), 51-60. https://doi. org/10.1080/0729436960150104

Doró, K., \& Habók, A. (2013). Language learning strategies in elementary school: The effect of age and gender in an EFL Context. JLLT, 4(2), 25-37.

Dreyer, C., \& Oxford, R. L. (1996). Learning strategies and other predictors of ESL proficiency among Afrikaans speakers in South Africa. In R. L. Oxford (Ed.), Language learning strategies around the world: Cross-Cultural perspectives (pp. 61-74). University of Hawaii.

Dubravac, V., Brdarević-Čeljo, A., \&Bećirović, S. (2018). The English of Bosnia and Herzegovina. World Englishes, 37(4), 635-652. https://doi.org/10.1111/weng.12347

Ehrman,M., \& Oxford,R.L.(1989).Effects of sexdifferences, careerchoice, and psychological type on adult language learning strategies. The Modern Language Journal, 73(1), 1-13. https://doi.org/10.1111/j.1540-4781.1989. tb05302.x

Ellis, R. (1994). The study of second language acquisition. Oxford University Press.

Gavriilidou, Z. \& Petrogiannis, K. (2016). Language learning strategy use of English FL learners in Greek schools: The role of type of school and educational level. International Journal of Research Studies in Language Learning, 5(4), 67-81. https://doi.org/10.5861/ijrsll.2016.1346

Goh, C. C. M., \& Foong, K. P. (1997). Chinese ESL students' learning strategies: A look at frequency, proficiency, and gender. Hong Kong Journal of Applied Linguistics, 2(1), 39-53.

Green, J. M., \& Oxford, R. L. (1995). A closer look at learning strategies, L2 proficiency, and gender. TESOL Quarterly, 29(2), 261-297. https://doi.org/10.2307/3587625

Griffiths, C. (2004). Language learning strategies: Theory and research (Occasional Paper No. 1). School of Foundations Studies.

Griffiths, C., \& Oxford, R. L. (2014). The twenty-first century landscape of language learning strategies: Introduction to this special issue. System, 43, 1-10. https://doi.org/10.1016/j.system.2013.12.009

Gunning P., \& Oxford R. L. (2014). Children's learning strategy use and the effects of strategy instruction on success in learning ESL in Canada. System, 43, 82-100. https://doi.org/10.1016/j.system.2013.12.012 
Habók, A., \& Magyar, A. (2018). The effect of language learning strategies on proficiency, attitudes and school achievement. Frontiers in Psychology, 8, Article 2358, 1-8. https://doi.org/10.3389/fpsyg.2017.02358

Kazamia, V. (2016). Gender and age impact on language learning strategy use: A research on Greek EFL learners. In Z. Gavriilidou, \& K. Petrogiannis (Eds.), Language learning strategies in the Greek setting: Research outcomes of a large-scale project (pp. 76-100). Saita Publications.

Little, D. G. (1991). Learner autonomy 1: Definitions, issues and problems. Authentik Language Learning Resources.

Magogwe, J. M., \& Oliver, R. (2007). The relationship between language learning strategies, proficiency, age and self-efficacy beliefs: A study of language learners in Botswana. System, 35(3), 338-352. https://doi. org/10.1016/j.system.2007.01.003

Mašić, A., Polz, E., \& Bećirović, S. (2020). The relationship between learning styles and GPA, school level and gender. European Researcher, 11(1), 51-60. https://doi.org/10.13187/er.2020.1.51

Marzano, R. J., \& Kendall, J. S. (2007). The new taxonomy of educational objectives (2nd ed.). Corwin Press.

Mertler, C. A., \& Reinhart, R. V. (2016). Advanced and multivariate statistical methods: Practical application and interpretation. Taylor \& Francis.

Mitits, L., Psaltou-Joycey, A., \& Sougari, A. (2016). Language learning strategy profiling of Greek primary / secondary school learners of English as a FL. In Z. Gavriilidou, \& K. Petrogiannis (Eds.), Language learning strategies in the Greek setting: Research outcomes of a large-scale project (pp. 26-41). Saita Publications.

Nyikos, M., \& Oxford, R. L. (1993). A factor analytic study of language-learning strategy use: Interpretations from information-processing theory and social psychology. Modern Language Journal, 77(1), 11-22. https:// doi.org/10.2307/329553

O’Malley, J. M., \& Chamot, A. U. (1990). Learning strategies in second language acquisition. Cambridge University Press.

O’Malley, J. M., Chamot, A. U., Stewner-Manzanares, G., Russo, R. P., \& Kupper, L. (1985). Learning strategy applications with students of English as a second language. TESOL Quarterly, 19(3), 557-584. https://doi. org $/ 10.2307 / 3586278$

Oxford, R. L. (1989). Use of language learning strategies: A synthesis of studies with implications for strategy training. System, 17(2), 235-247. https://doi.org/10.1016/0346-251X(89)90036-5

Oxford, R. L. (1990). Language learning strategies: What every teacher should know. Heinle.

Oxford, R. L. (1995). Gender differences in language learning styles: What do they mean? In J. M. Reid (Ed.), Learning styles in the ESL/EFL classroom (pp. 34-46). Heinle \& Heinle.

Oxford, R. L. (2001). Language learning styles and strategies. In M. Celce-Murcia (Ed.), Teaching English as a second or foreign language. Heinle \& Heinle.

Oxford, R. L. (2003). Language learning styles and strategies: An overview. In Learning Styles \& Strategies (pp. 1-25). GALA.

Oxford, R. L., \& Burry-Stock, J. A. (1995). Assessing the use of language learning strategies worldwide with the ESL/EFL version of Strategy Inventory for Language Learning (SILL). System, 23(1), 1-23. https://doi. org/10.1016/0346-251X(94)00047-A

Oxford, R. L., \& Cohen, A. D. (1992). Language learning strategies: Crucial issues of concept and classification. Applied Language Learning, 3(1\&2), 1-35.

Oxford, R. L., \& Ehrman, M. E. (1995). Adults' language learning strategies in an intensive foreign language program in the United States. System, 23(3), 359-386. https://doi.org/10.1016/0346-251X(95)00023-D

Oxford, R. L., Lavine, R., \& Amerstorfer, C. M. (2018). Understanding language learning strategies in context: An innovative, complexity-based approach. In R. L. Oxford, \& C. M. Amerstorfer (Eds.), Language learning strategies and individual learner characteristics: Situating strategy use in diverse contexts (pp. 5-29). Bloomsbury.

Oxford, R. L., \& Nyikos, M. (1989). Variables affecting choice of language learning strategies by university students. The Modern Language Journal, 73, 291-300.

Purpura, J. E. (1997). An analysis of the relationships between test takers' cognitive and metacognitive strategy use and second language test performance. Language Learning 47(2), 289-325. https://doi.org/10.1111/00238333.91997009

Radwan, A. A. (2011). Effects of L2 proficiency and gender on choice of language learning strategies by university students majoring in English. The Asian EFL Journal Quarterly, 13(1), 115-163.

Rizvić, E., \& Bećirović, S. (2017). Willingness to communicate in English as a foreign language in BosnianHerzegovinian EFL context. European Researcher, 8(3), 224-235. https://doi.org/10.13187/er.2017.3.224

Rubin, J., Chamot, A. U., Harris, V., \& Anderson, N. J. (2007). Intervening in the use of strategies. In A. D. Cohen, \& E. Macaro (Eds.), Language learner strategies: 30 years of research and practice (pp. 141-160). Oxford University Press. 
Schraw, G. (1998). Promoting general metacognitive awareness. Instructional Science, 26(1), 113-125. https://doi. org/10.1023/A:1003044231033

Shawer, S. F. (2016). Four language skills performance, academic achievement, and learning strategy use in preservice teacher training programs. TESOL Journal, 7(2), 262-303. https://doi.org/10.1002/tesj.202

Takeuchi, O., Griffiths, C., \& Coyle, D. (2007). Applying strategies to contexts: the role of individual, situational, and group differences. In A. D. Cohen, \& E. Marcaro (Eds.), Language learner strategies: 30 years of research and practice (pp. 69-92). Oxford University Press.

Wenden, A. L., \& Rubin, J. (Eds.) (1987). Learner strategies in language learning. Prentice Hall.

Wharton, G. (2000). Language learning strategy use of bilingual foreign language learners in Singapore. Language Learning, 50(2), 203-243. https://doi.org/10.1111/0023-8333.00117

Wong, L. L. C., \& Nunan, D. (2011). The learning styles and strategies of effective language learners. System, 39(2), 144-163. https://doi.org/10.1016/j.system.2011.05.004

Wu, Y.-L. (2008). Language learning strategies used by students at different proficiency levels. The Asian EFL Journal Quarterly, 10(4), 75-95. http://doi: 10.5539/ijel.v1n2p203

Yilmaz, C. (2010). The relationship between language learning strategies, gender, proficiency and self-efficacy beliefs: a study of ELT learners in Turkey. Procedia - Social and Behavioral Sciences, 2(2) 682-687. https://doi. org/10.1016/j.sbspro.2010.03.084

Vanderstoep, S. W., \& Johnson, D.D. (2008). Research methods for everyday life: Blending qualitative and quantitative approaches (vol. 32). John Wiley \& Sons. 